MedieKultur | Journal of media and communication research | ISSN 1901-9726

Article - Open issue

\title{
Public communication campaigns as mundane category
}

\section{Pernille Almlund, Nina Blom Andersen, Bente Halkier and Kim Christian Schrøder}

MedieKultur 2020, 68, 66-87

Published by SMID | Society of Media researchers In Denmark | www.smid.dk The online version of this text can be found open access at www.mediekultur.dk

\begin{abstract}
This article examines the public connection and understanding of public communication campaigns. Public communication campaigns are widespread, but the audience dimension of the campaign category itself is still a blind spot in research. Drawing on focus group interviews and a survey among Danish citizens, the article shows that public campaigns are recognized as a mundane communicative category. Moreover, drawing on theories of public connection and governmentality, we show how citizens receive and resist, accept and negotiate public campaigns.
\end{abstract}

Keywords

Public communication campaigns, public connection, engagement, governance 


\section{Studying campaigns}

Public issue campaigns are by definition about different issues. However, as we argue in this article, public issue campaigns also have sufficient characteristics in common across different issues to treat them analytically as the same kind of communication genre. Studies of specific public campaign issues such as health, risk and sustainability show that citizens are continuously being implied, framed and invited as co-actors in solving public issues, and that these campaigns attempt to socially regulate citizens into behaving benignly and sensibly towards each other concerning the specific issues (Coveney, 2000; Keller et al., 2016; De Krom, 2008). The advantage of using the broader category of public issue campaigns is that this enables research to analyze a more general media category as well as to tease out the common analytical elements across a variety of campaign types.

However, the research into public issue campaigns as a communication genre and citizens' relations with this kind of communication has a blind spot: the campaign category itself as understood by its audiences. This blind spot is due to the composition of the existing research. First, the more general communication literature has seen a focus on applied problem-solving in relation to public issue campaigning (e.g., Niederdeppe, 2014; Rice \& Atkin, 2013; Windahl \& Signitzer, 2009), rather than analyses of campaigns as a communicative phenomenon in itself. Second, most of the research on public campaigning and its audiences is either about political election campaigns with very little or no element of behavior change (e.g., Enli, 2017; Stechova \& Hajek, 2015; Takens et al., 2013), or about single cases of policy areas for behavior change, such as public health (e.g., Lupton, 2015), or sustainability (e.g., Shove, 2010). Finally, the existing studies of public issue campaigning have been dominated theoretically by various degrees of traditional transmission understandings of communication (Blue et al., 2016), implying an individualized deficit thinking about campaign audiences. Thus, the field of research about public issue campaigns seems to so far have been left rather untouched by the more general research on audiences and reception, which sees communication as a co-produced process and communication users as active agents (Dervin, 1989; Jensen, 2012; Schrøder, 2018).

In this article, we present citizens' constructions of public issue campaigns with particular focus on campaigns as a mundane social category, and on mundane ways of relating to public issue campaigns. These patterns of constructions come from a Danish research project on public issue campaigning.' By mundane social category and mundane ways of relating to campaigns, we simply mean everyday life understandings of categories and ways of relating to campaigns, which are embedded in daily life.

The analysis in the article is guided by the following research questions:

- How do public issue campaigns create forms of public connection and how do people engage in the campaigns?

- What empirical patterns can be recognized in citizens' reception of and relations to public issue campaigns? 
- How do citizens relate to the genre of public issue campaigns?

The article falls in five parts. First, we signpost our theoretical starting points. Second, we briefly outline the methodological design and empirical data-sets upon which the analysis rests. Third, empirical patterns in mundane constructions of the category "campaign" are presented. Fourth, we show empirical variations in constructions of citizens' mundane relations with campaigns. Finally, a conclusion is offered.

\section{Relations with campaigns: Engagement, public connection and governance}

Our analysis draws on a combined theoretical lens constituted by practice theories, theories of mediatization and public connection, and theories of governmentality. Across these theoretical domains, our study is indebted to insights from audience reception analysis (Schrøder, 2018).

\section{Engagement}

By engagement with campaigns, we mean citizens' discursive and normative orientation towards the content of the campaigns (Halkier, 2010, p. 29). In practice theory, it is argued that if one aims to understand people's orientations towards campaign messages, one should take one's analytical point of departure in their everyday practices, since campaign uses are rarely practices in themselves but exist as parts of diverse practices in everyday life (Gram-Hanssen, 2011). Hence, campaigns belong to mundane social categories, which are not normally devoted much attention, but which still play a role in people's lives because campaigns as a social category are interwoven with a multiplicity of everyday practices. In this perspective, citizens deal with campaigns as part of the multitude of practices they already carry out. Thus, we attempt to get closer to an analytical understanding of the experiencing of campaigns, even if it is neither a well-organized social practice, nor a separate practice or a discrete activity in itself (Keller \& Halkier, 2014, p. 39).

However, engagement is not understood here as an individual matter, performed by the subject, but rather engagement is performed as a part of mundane activities (Warde, 2005). These activities are carried out in interaction with others, which implies negotiations of the social regulation of how to do, because citizens hold each other mutually accountable for their mundane performances (Andersen, N. B., 2013, p. 274).

The term engagement in media research on citizens is often understood as something proactive, deliberate and even related to social movements or other kinds of activism. However, in this article we see engagement as something broader, which can cover deliberate, "activist" relations with public media content, but which can also cover more mundane, for instance conversational, ways of engaging with public mediated issues, such as the ones in campaigns (Halkier, 2016; Steensen et al., 2020). With the broadening of the term engagement, the analysis shows that there is considerable variation in the ways 
citizens handle the encounter with public issue campaigns, and how they make sense of and connect with them. In the encounter with campaigns, people reproduce, adapt and change existing practices in a complex of configurations.

\section{Mediatization and public connection}

Today, people's activities and sense-making are mediatized on a historically unprecedented scale (Hjarvard, 2013; Hepp, 2013). Campaigns in themselves are mediated more often than not, and there is often a mediated public negotiation following the launch of a campaign, as stakeholders and citizens discuss, for instance, a campaign's objectives or ethical implications, in mediated fora. Thus, a mediated product like a campaign has the potential to create connections or divisions, both between citizens and senders like authorities, NGOs and politicians who initiate and produce public campaigns, and between citizens who discuss, negotiate and engage more or less in campaigns, in face-toface situations and on social media.

Often, "mediatization" is equated with a high degree of media saturation of all aspects and levels of society, ranging from societal institutions to everyday life. However, mediatization can also be seen, more profoundly, as an overarching process of fundamental social and cultural transformations, or even as a meta-process on a par with globalization, secularization, and individualization (Hepp, 2013). Public issue campaigns constitute one formative vehicle of the mediatized age, whose communicative thrust encounters the interpretive repertoires of diverse audiences (Schrøder, 2017), as we shall see in the analysis below, where we illuminate what could be called people's "campaign literacy" (Livingstone et al., 2014).

Analysis of the audience reception of public issue campaigns has democratic implications, because engagement with public campaigns can be seen as a form of public connection. Following Couldry, Livingstone and Markham (2010), when people share their attention to and engagement in a publicly mediated product, this can be characterized public connection, defined as people's shared "orientation to a public world where matters of shared concern are [...] addressed" (Couldry et al., 2010 p. 3). The concept is thus "designed to capture an orientation to any of those issues affecting how we live together that require common resolution" (Couldry et al., 2010 p. 6). Although it is only a part of the population that engages in, say, a campaign on health and nutrition, and although they negotiate the communication in different ways, and only a segment of the engaged population may change their habitual practices as a consequence of the encounter, it is still the case that those who engage in the campaign are performing public connection.

We argue that instances of public connection which come about as a consequence of campaigns are often situated in mundane practices, since modes of engagement happen in diverse and subtle ways (Couldry et al., 2018, p. 2). Public connection is not to be expected by default, public disconnection is also a possibility (Couldry et al., 2018). As we shall demonstrate below, campaigns are resources for civic sense-making and public 
discourse in the broadest sense, sometimes agreed with, sometimes adapted to and sometimes resented and resisted (Schrøder, 1997).

\section{Governance}

Campaigns can also be regarded as a governance strategy. When campaigns are negotiated in social networks, it is often also a negotiation of the governance strategy attempts, which people experience in their reception of the campaigns. The citizens in our research project commented explicitly on how they saw most campaigns as coming from public authorities.

We understand governance through the lens of Foucault's governmentality concept (Foucault, 2008, 1991, 1982; Foucault in Fornet-Betancourt et al., 1987; Dean, 2006), given that the concept of governmentality underlines how the dominant governance in modern society is "conduct of conduct", meaning motivating the population and citizens as individuals to self-governance (Foucault, 1982; Foucault in Fornet-Betancourt et al., 1987). Since information or motivation for behavioral change is seldom mandatory in public campaigns, public campaigns are mostly such a request for self-governance. This governmental strategy should not be seen as delimited to public authorities but is imposed also by other providers of public issue campaigns like NGOs, education institutions and media that initiate or promote campaigns.

Governmentality implies how such steering-technologies make us keep an eye on each other and indirectly push each other in direction of right behavior. This type of governmental strategy, "turning us into decent people", as stated by one of the participants in the focus groups, can have moral and normative implications to all of us (Foucault, 1982; Dean, 2006).

Another common feature of the campaigns discussed in the focus groups is the participants' recognition of security. In the campaign data set, we sampled all campaign elements from 131 campaigns, and we can observe risk and security as part of up to 70 pct. of these campaigns. Risk and security can be seen as a commonly used governmental strategy, where authorities and institutions intend to motivate people in the direction of specific behavioral changes, with the argument that they are at risk of different kinds of problems if they do not change their behavior (Dean, 2006; Lupton, 1999).

Most frequently, we meet this governmental perspective in analyses of health campaigns (Karlsen \& Villadsen, 2017; Vallgårda, 2011), and less frequently in political campaigns (Almlund \& Andersen, N.B., 2017), but the perspective is not limited to these types and topics. Therefore, in combination with the practice theoretical perspective, we will explore how daily practices are not just mundane navigation and public connection, but also a handling and reception of governance. 


\section{Methodological design}

The empirical datasets we analyze in this article include the earlier mentioned focus group dataset and a representative survey.

The focus group dataset consists of eight focus groups with Danish citizens. Focus groups were chosen, because this kind of data can be seen as socially recognisable conversations about social norms (Barbour, 2007) in juggling and negotiating mundane practicing related to the issues of the campaigns. The sampling for the focus groups combined the strategies of segmentation and maximum variation (Kuzel, 1992). Each of the focus groups consisted of 6-8 participants from the same geographical area and the same stage in the life-course, and varied internally regarding gender and educational level: 3 focus groups with 18-25-year-old city-dwellers, 3 focus groups with 30-50-year-old people living in provincial towns or the countryside, and 2 focus groups with people above 55 living in provincial towns or the countryside. ${ }^{2}$

In the focus group discussions, the participants looked at campaign material from 12 different public issue areas. All the campaigns were discussed, but four campaigns were specifically chosen by us to be discussed more intensively. These four campaigns were: "Drive when you're driving!" from The Council for Safe Traffic, "Think before you ink" from The Environmental Agency and the Health Agency, "Denmark against catastrophes" from Red Cross, and "The new dietary advice" from The Food Agency. ${ }^{3}$ But the participants were also asked specifically about what the category "campaign" meant to them in the beginning of the focus groups, and to write this down. The focus group data were analysed by way of coding and categorising (Coffey \& Atkinson, 1996).

The survey dataset consists of a survey with a representative sample (Wolf et al., 2016) of the Danish population of 1,039 persons over 18. The survey was carried out as online interviews (CAWI), which is a particular advantage for surveys about media-texts such as public campaigns, because it allows the actual showing of campaign pictures and filmclips. The survey included a mixture of demographic background questions, a few general experiential questions, and a battery of seven similar experiential and attitude questions for each of the four campaigns mentioned above. The survey data were analyzed by way of simple univariate frequencies on all answer categories and bivariate frequencies on all answer categories with demographic variables.

\section{Campaigns as a generic mundane category}

First, we present the ways in which campaigns are understood generically by audiences, how they recognize the media category of campaigns and negotiate the characteristics of the genre. These understandings cut across the different kinds of campaigns, and thus 
support our assumption that it is useful to work with the broader category of public issue campaigns.

\section{Campaigns as information}

"Information" is the most distinctive word that is connected with campaigns across the different focus groups, and it is the only word associated with campaigns in all of the focus groups. This quote from focus group 7 is typical:

"And on my little notepad, I wrote 'information', just like Hans ${ }^{4}$ because they sort of want to inform about a concrete thing".

In some of the other groups, the association of campaigns with "information" is furthermore constructed as something people take for granted. This is a typical trait of mundane categories: they are not necessarily seen as being in need of explication. In focus group 5 , this is expressed in the following manner:

"I wrote 'information'. It is sort of implied". [...]

"I wrote 'information', 'influence' and 'pressure'. Information, it goes without saying".

Other frequently mentioned words associated with campaigns are "behavior change" and "influence", alongside with the word "commercials" or similar words (such as "profit" or "marketing"). The last kind of association interestingly suggests that citizens do not necessarily distinguish sharply between public, private and commercial producers of campaigns.

This is seen in focus group 8, when they discuss what a campaign is in general:

'But the first word I wrote was 'profit'. Because I thought, campaigns that's because we have to start buying something. Then I wrote 'information', because it doesn't have to be profit, it can also be the state wanting to tell us that if we do this, or eat that, or change our lives, or if we cycle with lights on our helmets, or the like, right?"

This overlap of associations between publically and commercially driven campaigns makes sense due to the growing amount of alliance-based campaigns in Denmark, with alliances across the public-private divide (Hansen, 2015).

Finally, communicative format seems to be at play in the participants' associations with campaigns as a phenomenon. The format of campaigns is clearly expected to be a form of mediated communication, including broader notions of public space, as it is here expressed in focus group 6 :

Ralf: "Of course, if you mostly travel with public transport, you see a whole lot of cam-

paigns..."

Dennis: "Yeah, there are many".

Ralf: "We have these stands for posters basically at every stop". 
Thus, campaigns are made sense of by the participants as information that may come from either public institutions or private organizations, where it is not always clear which is which, and which one can meet in a broad range of media in society. However, "information" is the characteristic that unites the participants in the focus groups.

\section{Target groups of campaigns}

The word "target group" has become part of the vocabulary of ordinary citizens, and is no longer just part of the toolbox of campaign producers and analysts. Participants' reference to the notion of target groups reflects their "campaign literacy", and it is another common characteristic of the findings from the study. With or without using the actual word target group, the participants construct whom they understand the campaigns to be directed towards. Interestingly, there is a distinct lack of constructions saying that this campaign is targeted at me as an individual person. This could be seen as surprising in light of the general tendency towards individualization and personalization of media-use in recent years. Instead, across the differences between the focus groups, participants either construct "target groups" along the lines of "all of us" statements, or "some other groups who are in need of it".

The "all of us" type of target group perception is expressed most clearly in focus group 6 , where the argument is based on linking campaign content to recognisable issues in everyday life:

"This is something that touches everybody. Most of this has to do with our everyday life. We bump into them all the time, more or less".

The "some other groups" type of target group argumentation is a kind of interpretation where the participants do not see themselves as being in need of particular campaigns.

In focus group 7, this kind of argument gets linked to potential societal-economic problems resulting from official dietary advice not being followed by those social groups perceived to be most in need of them. Thus, such groups of citizens are being constructed as problematic citizens:

\footnotetext{
"Yes, you can say, they have to do something, but then again, it's a question of reaching the right ones, if you think there is one or two healthy directions with food. Is it the right people you reach? Are they the ones who read this and hear about it? I'm not so sure. That's probably a general problem".
}

However, this kind of argumentation also "back-fired" socially in some of the group negotiations: When focus group 5 discussed the campaign about tattooing, several participants in a row had described getting a tattoo as involving a lack of awareness of potentially becoming an economic burden to society, due to the need to get the tattoo removed for health reasons. As a reaction to this, one of the participants who had a tattoo almost shouted: "Now I really feel offended!" 
Constructions like this one are often labelled "blaming the victim" arguments in the literature on public health (Dodds \& Chamberlain, 2016; Vitus et al., 2017), where those groups who suffer from some health challenge are blamed for their choices in the public debates and policy making.

Our survey data show that there are differences in the extent to which audiences recall the different campaigns mentioned in the survey. We asked if people recalled the same four campaigns that were discussed in the focus groups.

\begin{tabular}{|c|c|c|c|c|}
\hline Positive response to the question: & $\begin{array}{l}\text { "Drive the } \\
\text { car when } \\
\text { you drive } \\
\text { the car" }\end{array}$ & $\begin{array}{l}\text { "Think } \\
\text { before you } \\
\text { ink" }\end{array}$ & $\begin{array}{l}\text { "Denmark } \\
\text { against } \\
\text { catastro- } \\
\text { phes" }\end{array}$ & $\begin{array}{l}\text { "10 new diet } \\
\text { guidelines" }\end{array}$ \\
\hline “Have you seen this campaign before?” & $87 \%$ & $9 \%$ & $33 \%$ & $16 \%$ \\
\hline $\begin{array}{l}\text { "Do you experience that this campaign } \\
\text { touches on issues that you can recognize } \\
\text { or think about in your everyday life?" }\end{array}$ & $89 \%$ & $24 \%$ & $61 \%$ & $81 \%$ \\
\hline $\begin{array}{l}\text { "Do you believe that the campaign's mes- } \\
\text { sage is important?" }\end{array}$ & $97 \%$ & $66 \%$ & $77 \%$ & $82 \%$ \\
\hline
\end{tabular}

Table 1: Number of respondents who have answered yes to a-questions.

The traffic safety campaign was recalled by 87 pct., but the call for humanitarian donation, the request to live healthy and the call for the admonition to tattoo in a responsible way were only recalled by 33 pct., 16 pct. and 9 pct. respectively. ${ }^{5}$ However, the overall problems addressed by the specific campaigns are recognized by the majority of the respondents, who indicate that they think about the subjects of the campaigns in their everyday life in their answer to the question: "Do you experience that this campaign touches on issues that you can recognize or think about in your everyday life?" This is confirmed by 89 pct. on the question of traffic safety, 61 pct. concerning global distress, $81 \mathrm{pct}$. in case of the diet campaign and $24 \mathrm{pct}$. on the issue of safer tattooing. Even more respondents saw the messages of the campaigns as important. This was acknowledged by $97 \mathrm{pct}$. concerning traffic safety, $77 \mathrm{pct}$. on global distress, $82 \mathrm{pct}$. concerning the diet advice and $66 \mathrm{pct}$. in the case of safer tattooing. Since some of the respondents say that the message is important but not in relation to their own everyday life, the data indicate that some respondents find it more necessary to address the issue of the campaigns to other citizens than to themselves.

Both the quantitative and qualitative data sets document that people acknowledge the need to present issues like the ones in these campaigns to a broad audience. As mentioned above, we find that the participant citizens seem to identify two specific kinds of target groups for campaigns. One target group is "all of us", and the other type is "some other group - not us". The most interesting thing is perhaps the absence of the type "me 
as an individual", considering the individualistic approach in many campaigns, and the widespread debate in the literature about individualization of responsibility for societal problems (Blue et al., 2016; Gustafsson et al., 2011).

\section{Mundane ways of relating to specific campaigns}

Engagement in campaigns and awareness of governance technologies in campaigns are different aspects of citizens' relations with public issue campaigns, and both can be seen as public connection. Citizens "connect" (Couldry et al., 2010) and engage with mediated texts such as campaigns in different forms, and with different kinds of "publicness" and ways of connecting. Below we show the variation, which is characterized by ambiguity, since the patterns of relations and receptions of public issue campaigns are not going in one clear direction. We can identify several dynamics in the material, and some people do recognize the need for such campaigns, even if they question the specific campaigns we showed them. Concerning both engagement and governance, we divide the findings into dynamics which support the campaigns and their messages, and counter-dynamics, which refer to perceptions based on reluctance and opposition. Regardless of supporting or opposing campaigning, the respondents in the survey and participants in the focus groups are preoccupied with the consequences of campaigning, a sign we interpret as connectivity to the genre.

\section{Engagement and public connection}

The first dynamic pertaining to engagement is personal everyday experience. The participating citizens share with each other adaptations or changes to their ways of, e.g., car-driving or eating along the lines suggested by the campaign content, if they have had some kind of everyday experience themselves with the issue involved. This kind of engagement is expressed in focus group 1:

\footnotetext{
"I can relate to this one [campaign] about which chemicals in what food, but that's maybe because I am multi-allergic, so I am pretty involved in there not being all sorts of things in what I eat and in packaging and that kind of stuff. That's a kind of a thing in my daily life".
}

The second dynamic is events and stories in their social network. Here, the participants know or have heard about somebody in their network who has experiences with the campaign issue. These events and stories work in much the same manner as everyday experiences. A participant from focus group 8 gives an example of this when they are discussing a campaign about being alert to signs of bowel cancer:

"But I think it's true, as you say, the best instrument is if someone close to you gets a disease like this one. Someone you know who has been through something. You know, I have 
a good friend who has gotten the whole of his large intestine removed in two operations, because he had cancer".

The third dynamic is how "do-able" activities are (Halkier, 2010, p. 36), that is, how easy it is to carry out the adaptation of one's activities, both practically and socially. One of the most often-mentioned examples of this is the public systems of waste sorting in Danish municipalities, here from focus group 2:

\section{"We have this [campaign] about waste. You know, the only thing I think about is that I want to do it. You know, now I sort the bio waste [...] and we also sort paper, glass and waste".}

However, participants also mention and negotiate counter-dynamics that are seen as preventing the participants from engaging in the activities suggested in the campaigns. The first of these counter-dynamics is very simply a lack of everyday connection with the campaign issue and content. This dynamic is often triggered by the participant being in a different life-phase than the one the campaign addresses. Participants who do not have children or grandchildren are not paying attention to campaigns about trampoline safety procedures for example.

A second mundane counter-dynamic that seems to hinder engagement in particular campaign issues is if the campaign in question is perceived as being overloaded with information that is difficult to adapt into daily life. This was the case with a campaign on chemicals in foodstuff from a public agency, which had a lot of text, for instance in focus group 6:

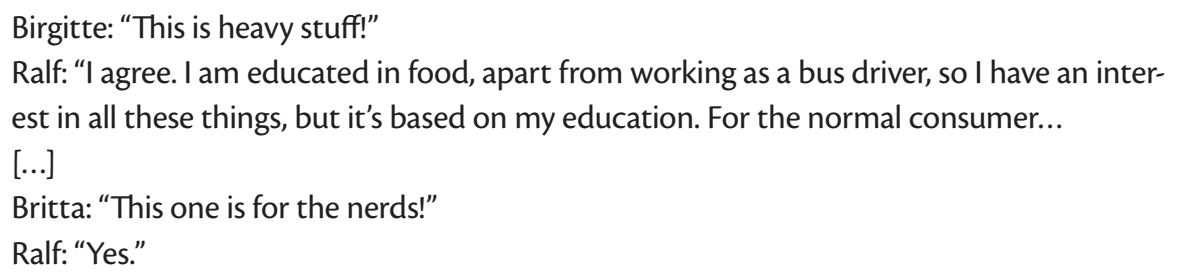

But apart from overload leading to lack of engagement with the campaign, information can also, thirdly, be understood by the participants as the wrong kind of information. Across the focus group differences, this was particularly clear when the participants were negotiating their degree of engagement with the campaign about official dietary advice. Healthier eating is one of the public issues where there are strongly competing mediated repertoires about what to do (Halkier, 2020), so the expert knowledge in campaigns for the official dietary advice becomes negotiated in relation to food repertoires such as vegetarianism, paleo, etc. This exchange from focus group 1 shows this counter-dynamic and the highly mediatized nature of campaigns: 
Paula: "What I think about when I look at this, now l'm very preoccupied with diets and health, and it says so down here with whole-grain, that you have to eat some amount of oat and rye bread, and the only thing I think is when you talk about paleo and stone age diet, where they say you shouldn't. So if it were to speak to me, then I get really confused, because I try to live according to the paleo diet, and there you are not supposed to have all that... I'm confused."

Lilly: "But the health authorities don't recommend paleo..."

Paula: "But in the media, it's just all over the place."

Lone: "And in TV food programs..."

The media repertoire around the campaigns about healthier eating is broad: Programs on cooking, documentaries, news on scientific findings concerning nutrition, just to mention a few. Campaigns are in this regard only one way of getting advice, which, as the participants above say, leads to "confusion".

A final counter-dynamic identified in the focus groups is when activities encouraged in the campaign are not inviting collective participation, which tends to hinder some of the participants in adapting their activities. This is the case when campaigns only mention or address the individual citizen or consumer as societal actor, instead of also referring to movements, organizations and institutions. Thus, in response to campaigns, participants often justify their not engaging in implementing, adapting or changing activities in every-

\begin{tabular}{|c|c|c|c|c|}
\hline & $\begin{array}{l}\text { "Drive the } \\
\text { car when } \\
\text { you drive } \\
\text { the car" }\end{array}$ & $\begin{array}{l}\text { "Think } \\
\text { before you } \\
\text { ink" }\end{array}$ & $\begin{array}{l}\text { "Denmark } \\
\text { against } \\
\text { disasters" }\end{array}$ & $\begin{array}{l}\text { "10 new diet } \\
\text { guidelines" }\end{array}$ \\
\hline Feel overwhelmed by information & $1 \%$ & & $2 \%$ & $2 \%$ \\
\hline $\begin{array}{l}\text { Plan to follow the advice of the campaign, } \\
\text { though it can be hard to follow through }\end{array}$ & $8 \%$ & $1 \%$ & $13 \%$ & $25 \%$ \\
\hline $\begin{array}{l}\text { Get annoyed that I have to relate to the } \\
\text { campaign }\end{array}$ & $1 \%$ & $3 \%$ & $7 \%$ & $3 \%$ \\
\hline Appreciate getting good advice & $14 \%$ & $6 \%$ & $4 \%$ & $15 \%$ \\
\hline $\begin{array}{l}\text { Try to find shortcuts in order to follow the } \\
\text { advice from the campaign }\end{array}$ & $1 \%$ & & $1 \%$ & $5 \%$ \\
\hline Get bad conscience & $7 \%$ & & $15 \%$ & $5 \%$ \\
\hline Experience support of what I already do & $37 \%$ & $13 \%$ & $11 \%$ & $16 \%$ \\
\hline $\begin{array}{l}\text { Talk with e.g. friends, colleagues and } \\
\text { family about the campaign }\end{array}$ & $15 \%$ & $10 \%$ & $6 \%$ & $2 \%$ \\
\hline I forget it & $2 \%$ & $15 \%$ & $8 \%$ & $7 \%$ \\
\hline I do nothing & $11 \%$ & $47 \%$ & $28 \%$ & $17 \%$ \\
\hline I don't know/Do something else & $4 \%$ & $5 \%$ & $6 \%$ & $3 \%$ \\
\hline
\end{tabular}

Table 2: "What do you typically do, when you meet a campaign like the one we present here?" 
day life by arguing that other and more collectively organized activities would matter more or have a greater impact on societal problems.

Our survey data supplement the variation in findings from the focus groups on both dynamics and counter-dynamics governing how people handle the encounter and connect with a campaign.

The distribution of typical reactions varies depending on the message (see Table 2; percentages in bold type highlight salient answers). A vertical reading of the numbers reveals that the campaign about car driving is most frequently recognized as support of the respondents' existing practice - a dynamic of engagement that can probably be explained by many respondents' everyday experience of driving. Conversely, campaigns calling for donations to international disasters and careful tattooing are most frequently not followed by any action, since there is a lack of everyday connection for many: Tattooing is only experienced by some people, and many do not experience third world problems as relevant. However, the humanitarian aid campaign can evoke bad conscience. In contrast, guidelines for healthy living are most frequently met with good intentions, but are believed to be hard to follow through. Thus, campaigns are deliberate invitations to engagement, and it is reflected in the survey results that they do function this way.

Thus, both the qualitative and quantitative datasets bear witness to both dynamics and counter-dynamics for how people engage in public issue campaigns.

\section{Governance and disciplining}

The other main form of connecting with public issue campaigns among the Danish citizens was seen when people expressed their awareness of governance technologies embedded in campaigns. Across the focus groups, we found both acceptance and trust in institutions and expert knowledge. This comes out clearly in focus group 2 in their discussion of the public issue campaigns as genre:

\footnotetext{
"If I go into such a Facebook page, I'll immediately think, ehm, is this really correct? Who is behind this? But if it's a poster where you see the royal crown and Health Authority, alright then it's probably right. Then they already have my trust there. So that's how it is in general with campaigns, for me, that I can see very quickly who is behind it".
}

In Denmark, public institutions and authorities are generally understood as very trustworthy (Andersen, J. et al., 2017). The royal crown is often integrated in the logos of these institutions.

One way of navigating a campaign's attempts to govern everyday life activities is when the participants construct campaigns as socially expected to make citizens act in certain ways. Thus, campaigns are interpreted as some sort of overall attempt to influence the attitudes and behaviors of citizens on a number of issues in society. This is exemplified by a participant in focus group 6 : 


\begin{abstract}
"All these campaigns about diet and booze and smoking and physical exercise. That's the long tough pull. It takes decades to turn that ship around, cause if you ask any wellinformed Dane, can you smoke, can you drink, can you eat too fatty and unhealthy, and can you ignore exercising, they all know that the answer is no. [...] We all know this, but you have to make campaigns to try to work on people to slowly try to change their behavior, and that's what they're doing and have been doing for the past 50 years".
\end{abstract}

Across the differently aged focus groups, the participants explain how the campaigns from the authorities generally try to push us in a new direction in our daily life. The participants are especially aware of the campaigns' attempts to change our behavior and to inspire us to live healthier. In focus group 5, the use of "inclusive we" shows that they identify with the governance agents:

\footnotetext{
"Well, I think behavior change, when society tries to educate people's opinion. That is often what it is, right. We want people to change their behavior. We want them to drive with a seat belt. We want them to buckle up their kids. We want them to stop smoking. Well, I just think that campaigns are generally like that".
}

The participants in the focus groups even point out how authorities try to direct citizens and everyday life in more specific directions. Thus, participants indicate that they are aware of not only the immediate intention of governance on the subject the campaign deals with, but also the intention of disciplining them as citizens in general. This is a reception of campaigns we found across the age- and life-situation differences between and within focus groups. Again, in focus group 5, this comes out clearly: "Well, they want us to eat healthy, live healthy, speak decently and drive nicely".

Even though they are aware of how campaigns are used as a governance strategy disciplining us all to be citizens in a specific way, they also express how campaigns are a necessity and somehow a legitimate strategy applied by authorities and others in order to secure certain ways of living and behaving among a population. Here are quotes from focus group 4:

Rasmus: "As Bodil says, we are moving. It is going slowly. It is one step at a time".

Bodil: "But, it is due to the campaigns that we are moving".

Rasmus: "Then, at one point, it will probably also be forbidden to smoke, when we are dead and gone".

Betinna: "But, we cannot do without campaigns".

One citizen from focus group 5 expressed it in a very humorous way and made all participants and interviewers laugh: "Earlier on, we went to church and got preached at, now we get campaigns".

So, the participants have a strong feeling of being regulated by governance technologies embedded in campaigns. People feel directed by campaigns, and as it is indicated in 
the last quote with the shift from churches to campaigns, the more indirect steering once instigated by the church is now instigated by the authorities (Foucault, 2008, 1982).

Without using the Foucauldian concepts, the participants express how campaigns convey "conduct of conduct" (Foucault, 1982), as they remind citizens what is the right thing for them to do as individuals - how they are supposed to conduct self-steering. Expressions that are often used are, for example, "a reminder" or "a gentle poke". In focus group 4, the participants talk about this expectation in their conversation about the drive safely campaign after being asked whether they can use this traffic campaign and the message of driving safely for anything:

Bo: "Then I would like to follow up by saying that I can. It can poke at my bad conscience, and it's bad because I know from my own experience that I'm not... focused in these situations. And I've also seen how I have sometimes been very close to bumping into the back of a car".

Bodil: "I can only agree with you. We must say so. So it also pokes at my bad conscience. And that is precisely why they repeat it again and again, because otherwise you forget them".

In some cases, conduct of conduct also gives citizens a "feel-good effect", as this quote concerning campaigns on waste sorting from focus group 4 shows:

"This gives me an enormous 'feel-good effect'. These piles of waste that you drive to the recycling depot every two weeks. Then, you are a good citizen".

Whether it serves to remind one of common sense, to achieve a feel-good effect or to be judgmental towards other citizens, the interview participants understand that they as individuals are in charge of doing life right (Foucault, 2008).

Our survey data also show that citizens actually expect such attempts to be regulated and to discipline themselves. The most striking quantitative finding to supplement data from the focus groups is that despite the respondents' divergent degree of recall of the four specific campaigns, and despite the differences in their experience of relevance to their own lives, on the whole they do seem to acknowledge the legitimacy of the four messages. Furthermore, a significant part of the respondents answer that they believe their actions make a difference to public issues (see Table 3).

Asking the survey respondents if citizens need to undertake the co-responsibility that campaigns invite to, the dominant answers (not shown here) are: "We need both legislation and campaigns to support the solving of problems together with the public sector" (35 pct.), "You have to start with yourself" (26 pct.), "I act, if it affects me" (15 pct.) and "People can do what they want" (12 pct.). This complex of answers covers both the idea of individualization and collectiveness concerning citizens' co-responsibility. This quantitative finding is interesting compared to the results from the focus groups, since both methods reveal a complex intersection of sense-making concerning the relation between 
Article: Public communication campaigns as mundane category

$\begin{array}{lrrrr} & \begin{array}{l}\text { "Drive the } \\ \text { car when you } \\ \text { drive the car" }\end{array} & \begin{array}{l}\text { "Think } \\ \text { before you } \\ \text { ink" }\end{array} & \begin{array}{l}\text { "Denmark } \\ \text { against } \\ \text { disasters " }\end{array} & \begin{array}{l}\text { "10 new diet } \\ \text { guidelines" }\end{array} \\ \text { "To some extent" and "To a large extent" } & 87 \% & 41 \% & 51 \% & 67 \% \\ \text { "To a low extent" and "Not at all" } & 8 \% & 48 \% & 43 \% & 28 \% \\ \text { "Don't know" } & 4 \% & 11 \% & 6 \% & 6 \%\end{array}$

Table 3: Answers to the questions concerning each of the four campaigns (e-questions) Question: "To what extent do you believe that your acts in everyday life can make a difference in order to solve societal problems like ... as touched on in this campaign?"

the responsibility of the individual citizen and the society as collective. The variations in understanding campaigns as targeted towards me or the others (as presented above), are displayed in both the quantitative and qualitative inquiries, although, not surprisingly, the outcomes are more static and less subtle in the survey.

\section{Negotiations of resistance}

A different way of navigating such governing attempts by campaigns is found when the participants express that campaigns partake in an attempt to regulate citizens in less legitimate ways. Here, catchwords used among the citizens are "the pointed finger", "big mother society" and "being talked down to". Focus group 7 is leaning towards such more critical constructions of the less acceptable aspects of the purpose of campaigns:

\footnotetext{
Niels-Ole: "It can come across as a little sermonizing - I will not say like knowing better, but a bit like this: 'Come on and read this, it's sensible'".

Hans: "I would like to take it a step further and say, that I feel a bit smothered. You know, in general, right?"
}

All these catchwords show that this type of regulation is negotiated, resented and resisted among some of the participants, because it is related to what the citizens experience as some sort of moralizing about their everyday life. In focus group 5, Leif explains this:

\footnotetext{
"My biggest problem with these campaigns is that some holy person comes along and tells me that 'now you are certainly not supposed to'... No but hell, I grew up in the sixties and seventies. We climbed trees and stole apples, without them being washed. Rumour has it that apparently none of us have died from this yet, and I think that the whole thing goes over the top".
}

Just like campaign-derived regulation of behavior can be seen as not so acceptable, this resentment can also entail a lack of trust in governing institutions and expert knowledge, as seen here in an extract from focus group 3. 
"I'm a little bit against everything that says 'official'. It's probably just me. When it is official dietary advice, then I think that it is something that gets dictated - more so, than if it had not been called official. It could have just said 'dietary advice'. That would have been fine by me..."

It is also mentioned how the campaigns of government agencies are a delicate matter when it comes to the balance between care and individual freedom, such as here in focus group 1:

"But the Health Authority that we talked about earlier, I'm always a bit irritated with them, I always think that they are a bit paternalistic. Although, you can sort of follow, it seems logical to want to improve people's health, but it's also a balance with the freedom of the individual".

This negotiation of resistance underlines how the interview participants feel governed and pushed by campaigns. With Foucault, we can call the resistance "struggles against the 'government of individualization'” (Foucault, 1982, p. 781). These struggles confirm that campaigns are steering technologies based on the idea of indirect steering (Lupton, 1999; Dean, 2006; Foucault, 1982), which citizens follow to some extent, but don't comply with fully.

\section{Care and security}

Despite the citizens' resistance to being patronized by campaigns' big brother discourses, they are, as indicated above, aware of and accept that campaigns are also part of the state's caring strategy. This was expressed in focus group 5 and 4, respectively, where two respondents point out what they initially have stated as general associations about campaigns in the beginning of the focus group sessions:

\footnotetext{
'I have 'information', 'influence' and 'pressure' [...]. Pressure is not meant to be misunderstood as if something is imposed on people, but as if you press a population group in one direction, for example drunk drivers not to drive. Then you press, but justly of course, in a positive direction".

"Yes, well, I do start positively with 'motivation'. I think like socially related. Society - big brother - cares for me".
}

This double binding of campaigns as both steering and caring is interpreted as positive manipulation by one of the participants in focus group 6:

"I think of campaigns as a way where, through different means, you try to get people to act in a certain direction. The direction you wish yourself. It is a type of manipulation, but not negatively meant. Positive manipulation".

Asking all the focus groups at the end of the session if they saw any commonalities between the campaigns they had seen, they answered that besides being mostly from 
public authorities, the campaigns focus on security. This is expressed here in focus groups 4 and 1:
"And then I have written 'safety', because often it is about safety. With seat belt, with helmet, and take care of the children. It's about safety. It's about showing a good example as an adult, so you use the bike helmet, then the children will do the same, and get it through the back door".
"I've written 'safety'. That's because I think there are many campaigns about driving in the traffic and being aware on the roads. At least those kinds of advertisements or campaigns have impressed me".

These utterances show that the focus group participants are aware of how the authorities take care of them through campaigns, exactly because the campaigns often give them good advice about safety like bicycle helmets. Focus on safety for the population is what Foucault calls "mechanism of security" (Foucault, 2008; Dean, 2006), which is established exactly with the intention to care for people and to motivate them to take care of themselves (Foucault, 1988). Thus, among the focus group participants, there is a recognition that campaigns express care and manipulate at the same time.

\section{Conclusion}

Engagement in campaigns and awareness of governance technologies in campaigns are different aspects of citizens' relations with public issue campaigns, which can both be seen as expressions of public connection. Public issue campaigns are recognized as a mundane communicative category both across differences of policy area content and across demographic differences among citizens. As the qualitative material and the survey findings presented in this article show, people often demonstrate that they are oriented towards the existence of the campaigns, and are fully aware of the intentions with campaigns. When they indicate what campaigns are, they pinpoint that campaigns can be both public, private and commercial, and often citizens do not distinguish sharply between these categories. Also, the concept "target group" has become part of ordinary language, and in this analysis specified to be either "all of us" or "some other groups who are in need of it". An interesting observation is the absence of the type "me as an individual" as a reception category, since we have otherwise witnessed a tendency towards individualization of media use in recent years.

The data material does not display unambiguous attention or involvement that results in people following the advice given; on the one hand, it does show some form of engagement, and thus public connection, in the multimodal meanings audiences create from the campaigns. On the other hand, the data material also shows a range of counterdynamics, meaning that people sometimes do not engage, due to for example overload of information or if campaigns do not invite recipients to collective participation. 
Another perspective of public connection that shows up in the data material is the perception of public communication campaigns as governance, where campaigns are understood as being based on an overall intention to influence the attitude and behavior of citizens. The interviewees expressed that typically this sort of campaign came from public authorities and mostly from health authorities. They were strongly aware of how the campaigns indirectly try to show them how they as individuals are in charge of doing life right.

Again, we see no unambiguous perception of these governance-strategies; on the one hand, they are perceived as necessary, and in some cases, establishing a feel-good effect. On the other hand, the advice given in the campaigns is always negotiated and sometimes resisted, since people don't like to be dictated or patronized, and definitely don't like the pointed finger.

The general insight to be taken from this study, perhaps, is that the ordinary people in our focus groups can be said to be campaign literate.

\section{Noter}

1 The research project, "Public campaigns and everyday agency", was funded under Centre for Power, Media and Communication, Roskilde University, Denmark, 2013-2016. The research project established a varied campaign dataset consisting of a focus group dataset, a representative survey, a sample of 131 campaigns launched over a year (approximately 4,500 campaign elements) and a historical sample of campaigns within health and environmental issues.

2 See list of focus groups as appendix, just above the reference list.

3 The four different main campaigns were chosen in order to represent the most relevant analytical differences in the area of public issue campaigns. The four campaigns vary with regards to actor type of sender (public or private organization), with regard to type of purpose (e.g., raise support, change knowledge, or change action), and with regard to the amount of different kinds of media involved.

4 All names are pseudonyms.

5 We do encourage the reader to not interpret these percentages as signs of the "success" of the four campaigns: They were aimed at differently sized target groups, and the channels of distribution differ and exposure varies.

\section{Appendix}

List of focus groups

Focus group 1, young people aged 18-25 years, living in a city

Focus group 2, young people aged 18-25 years, living in a city

Focus group 3, young people aged $18-25$ years, living in a city

Focus group 4, people aged 30-50 years, living in a provincial town or in the countryside

Focus group 5, people aged 30-50 years, living in a provincial town or in the countryside

Focus group 6, people aged 30-50 years, living in a provincial town or in the countryside

Focus group 7, people aged 55 plus, living in a provincial town or in the countryside

Focus group 8, people aged 55 plus, living in a provincial town or in the countryside 


\section{References}

Almlund, P., \& Andersen, N.B. (2017). Lokaldemokrati på spil. Et casestudie af et dansk kommunalvalg. Copenhagen: Samfundslitteratur.

Andersen, N.B. (2013). Negotiations of acknowledgement among middle class residents: An analysis of post disaster interactions and performance in a Danish context. International Journal of Mass Emergencies \& Disasters, 31(2), 270-292.

Andersen J., Hede, A., \& Andersen, J.G. (2017). Tryghedsmåling 2017: Tilliden til samfundets bæerebjaelker. Copenhagen: TrygFonden

Barbour, R. (2007). Doing Focus Groups. London: Sage.

Blue, S., Shove, E., Carmona, C., \& Kelly, M.P. (2016). Theories of practice and public health: Understanding (un)healthy practices. Critical Public Health, 26(1), 36-50. https://doi.org/10.1080/09581596.2014.980396.

Coffey, A., \& Atkinson, P. (1996). Making Sense of Qualitative Data. London: Sage.

Couldry, N., Livingstone, S., \& Markham, T. (2018). The public connection project ten years on. Originally published in M.A. Guerrero, \& A. Arriagada, Conexión Pública: practices cívicas y uso de medios en cinco paises (pp. 145-169). Mexico: Universidad Iberoamericana. Available in LSE Research Online: June 2018. http://eprints.Ise.ac.uk/88284/1/Livingstone_Public\%20Connection\%20Project_Accepted.pdf

Couldry, N., Livingstone, S., \& Markham, T. (2010). Media Consumption and Public Engagement. Beyond the Presumption of Attention. London: Palgrave Macmillan. https://doi.org/10.1057/9780230800823

Coveney, J. (2000). Food, Morals and Meaning: The pleasure and anxiety of eating. London, Routledge.

Dean, M. (2006). Governmentality: Magt \& styring I det modern samfund. Copenhagen: Forlaget Sociologi.

De Krom, M.P.M.M. (2008). Understanding consumer rationalities: Consumer involvement in European food safety governance of avian influenza. Sociologia Ruralis, 49(1), 1-19. https://doi.org/10.1111/j.14679523.2008.00474.x.

Dervin, B. (1989). Audience as listener and learner, teacher and confidante: the sense-making approach. In R.E. Rice, \& C. K. Atkin (Eds.), Public Communication Campaigns (pp. 67-86). London: Sage.

Dodds, A., \& Chamberlain, K. (2016). The problematic messages of nutritional discourse: A case-based critical media analysis. Appetite, 108(1), 42-50. https://doi.org/10.1016/j.appet.2016.09.02.

Enli, G. (2017). Twitter as arena for the authentic outsider: Exploring the social media campaigns of Trump and Clinton in the 2016 presidential election. European Journal of Communication, 32(1), 50-61. https:// doi.org/10.1177/0267323116682802.

Foucault, M. (2008). Sikkerhed, territorium, befolkning. Forelesninger på Collège de France 1977-1978. Copenhagen: Hans Reitzels Forlag. https://doi.org/10.1177/00016993100530010105.

Foucault, M. (1991). Governmentality. In C.G. Burchell , \& P. Miller (Eds.), The Foucault Effect: Studies in governmentality (pp. 87-104). Chicago: The University of Chicago Press. https://doi.org/10.7208/chicago/9780226028811.001.0001.

Foucault, M. (1988). Technologies of the Self. UK: Tavistock Publication.

Foucault, M. (1982). The Subject and Power. Critical Inquiry, 8(4), 777-795.

Fornet-Betancourt, R., Becker, H., Gomez-Müller, A., \& Gauthier, J. D. (1987). The ethic of care for the self as a practice of freedom: An interview with Michel Foucault on January 20, 1984 (J.D. Gauthier, Trans.). Philosophy \& Social Criticism, 12(2-3), 112-131. https://doi.org/10.1177/019145378701200202.

Gram-Hanssen, K. (2011). Understanding change and continuity in residential energy consumption. Journal of Consumer Culture, 11(1), 61-78. https://doi.org/10.1177/1469540510391725.

Gustafsson, U., Wills, W., \& Draper, A. (2011). Food and public health: Contemporary issues and future directions. Critical Public Health, 21(4): 385-93. https://doi.org/10.1080/09581596.2011.625759.

Halkier, B (2010). Consumption Challenged: Food in Medialised Everyday Lives. Farnham, Ashgate. https:// doi.org/10.4324/9781315573755. 
Halkier, B. (2016). Civic engagement by invitation? Citizen negotiations about public media framings of everyday life responsibilities for societal problems. In H.K. Nielsen (Ed.), The Democratic Public Sphere (pp. 289-318). Aarhus: Aarhus Universitetsforlag.

Halkier, B. (2020). Mundane negotiations around official Danish dietary advice: Connection, expert knowledge, and everyday agency. Critical Public Health, 30(3), 294-305. https://doi.org/10.1080/09581596.201 8.1554244.

Hansen, S.E. (2015). Communication campaigns, food consumption and change of practices in everyday family life: An analysis of strategic communication on food and citizenship in Region Zealand, Denmark [PhD Thesis, Roskilde University, Denmark].

Hepp, (2013). Cultures of Mediatization. Cambridge: Polity.

Hjarvard, S. (2013). The Mediatization of Culture and Society. London: Routledge.

Jensen, K.B. (2012). A Handbook of Media and Communication Research (2nd ed.). London: Routledge.

Karlsen, M.P., \& Villadsen, K. (2017). Det velafbalancerede subjekt: sundhedsfremme, guvernmentalitet og spørgsmål om nydelse og begær. In M.P. Karlsen, \& K. Villadsen (Eds.), Sundhed og Magt (pp. 147-178). Copenhagen: Hans Reitzels Forlag. https://doi.org/10.22439/dansoc.v19i3.2841.

Keller, M., \& Halkier, B. (2014). Positioning consumption: A practice theoretical approach to contested consumption and media discourse. Marketing theory, 14(1), 35-51. https://doi. org/10.1177/1470593113506246.

Keller, M. Halkier, B. \& Wilska, T.A. (2016). Policy and governance for sustainable consumption at the crossroads of theories and concepts, Environmental Policy and Governancel, 26, 75-88.

Kuzel, A.J. (1992). Sampling in qualitative inquiry. In B.F. Crabtree, \& W.L. Miller (Eds.), Doing Qualitative Research (pp. 31-44). London: Sage.

Livingstone, S., Wijnen, C.W., Papaioannou, T., Costa C., \& Grandio, M. (2014). Situating media literacy in the changing media environment: Critical insights from European research on audiences. In $\mathrm{N}$. Carpentier, K.C. Schrøder, \& L. Hallett (Eds.), Transforming Audiences: Shifting audience positions in late modernity (pp. 210-227). London: Routledge.

Lupton, D. (2015). The pedagogy of disgust: The ethical, moral and political implications of using disgust in public health campaigns. Critical Public Health, 25(1), 4-14. https://doi.org/10.1080/09581596.2014.885115.

Lupton, D. (1999). Risk. New York: Routledge.

Niederdeppe, J. (2014). Conceptual, empirical and practical issues in developing valid measures of public communication campaign exposure. Communication Methods and Measures, 8(2), 138-161.

Rice. R.E., \& Atkin, C.K. (2013). Public communication campaigns (4th ed.). London: Sage.

Schrøder, K.C. (1997). Cynicism and ambiguity: British corporate responsibility advertisements and their readers. In M. Nava, A. Blake, I. MacRury \& B. Richards (Eds.), BUY THIS BOOK Studies in Advertising and Consumption (pp. 276-290). London: Routledge.

Schrøder, K.C. (2017). Towards the 'audiencization' of mediatization research? Audience dynamics as co-constitutive of mediatization processes. In O. Driessens, G. Bolin, A. Hepp, \& S. Hjarvard (Eds.), Dynamics of Mediatization (pp. 85-115). London: Palgrave macmillan. https://doi.org/10.1007/978-3319-62983-4_5.

Schrøder, K.C. (2018). Audience reception. In P.H. Napoli (Ed.). Mediated Communication: Handbooks of Communication Science (vol. 7) (pp. 105-128). Berlin: Mouton De Gruyter. https://doi. org/10.1515/9783110481129-008.

Shove, E. (2010). Beyond the ABC: Climate change policy and theories of social change. Environment and Planning A, 42(6), 1273-1285. https://doi.org/10.1068/a42282. 
Stechova, M. \& Hajek, R. (2015). Faithful confidants or fickle coat-changers? Audience's perceptions of celebrities in political campaigns before the first direct presidential election in the Czech Republic. European Journal of Communication, 30(3), 337-352. https://doi.org/10.1177/0267323115577308.

Steensen, S., Ferrer-Conill, R., \& Peters, C. (2020). Theory of audience engagement. Paper presented to the Journalism Studies Division, ICA conference, Australia, 20-25 May, 2020.

Takens, J., van Atteveldt, W., van Hoof, A., \& Kleinnijenhuis, J. (2013). Media logic in election campaign coverage. European Journal of Communication, 28(3), 277-293. https://doi.org/10.1177/0267323113478522.

Vallgårda, S. (2011). Addressing individual behaviours and living conditions: Four Nordic public health policies. Scandinavian Journal of Public Health, 39(6), 6-10. https://doi.org/10.1177/1403494810378922.

Vitus, K., Tørslev, M.K., Ditlevsen, K., \& Nielsen, A.L. (2017). Body weight management and dilemmas of health responsibility for vulnerable groups in the changing Danish welfare state: A comparative case analysis. Critical Public Health, 28(1), 22-34. https://doi.org/10.1080/09581596.2017.1286294.

Warde, A. (2005). Consumption and theories of practice. Journal of Consumer Culture, 5(2), 131-153.

Windahl, S. \& Signitzer, B. (2009). Using Communication Theory: An introduction to planned communication. London: Sage.

Wolf, C., Joye, D., Smith, T.W., \& Fu, Y.C. (2016). The Sage Handbook of Survey Methodology. London: Sage. https://doi.org/10.4135/9781473957893.

Pernille Almlund

Associate professor

Department of Communication and Arts

Roskilde University

almlund@ruc.dk

Nina Blom Andersen

Reader

Department of Management and Administration

University College Copenhagen

nban@kp.dk

Bente Halkier

Professor

Faculty of Social Sciences

University of Copenhagen

beh@soc.ku.dk

Kim Christian Schrøder

Professor

Department of Communication and Arts

Roskilde University

kimsc@ruc.dk 